\title{
Handbook of Florida Water Regulation: Solid Waste Management ${ }^{1}$
}

Michael T. Olexa, Luke D'Isernia, Laura Minton, Dulcy Miller, and Sarah Corbett ${ }^{2}$

\section{Preface}

This handbook is designed to provide an accurate, current, and authoritative summary of the principle Federal and Florida laws that directly or indirectly relate to agriculture. This handbook should provide a basic overview of the many rights and responsibilities that farmers and farmland owners have under both Federal and Florida laws as well as the appropriate contact information to obtain more detailed information. However, the reader should be aware that because the laws, administrative rulings, and court decisions on which this handbook is based are subject to constant revision, portions of this publication could become outdated at anytime. Several details of cited laws are also left out due to space limitations.

This handbook is distributed with the understanding that the authors are not engaged in rendering legal or other professional advice, and the information contained herein should not be regarded as a substitute for professional advice. This handbook is not all inclusive in providing information to achieve compliance with the Federal and Florida laws and regulations governing water protection. For these reasons, the use of these materials by any person constitutes an agreement to hold harmless the authors, the Florida Cooperative Extension Service, the Institute of Food and Agricultural Sciences, and the University of Florida for any liability claims, damages, or expenses that may be incurred by any person as a result of reference to or reliance on the information contained in this handbook.

\section{Who Regulates Solid Waste Management?}

Both federal and state governments have enacted Resource Conservation and Recovery Act (RCRA) legislation to deal with the disposal of solid wastes. The federal rules are administered by the Environmental Protection Agency (EPA), and the state rules are administered by the Department of Environmental Protection (DEP).

Both RCRAs are aimed at protecting public health and the environment and at recycling or

1. This is EDIS document FE611, a publication of the Food and Resource Economics Department, Florida Cooperative Extension Service, Institute of Food and Agricultural Sciences, University of Florida, Gainesville, FL. Published December 2005. Please visit the EDIS website at http://edis.ifas.ufl.edu.

2. Michael T. Olexa, Professor, Food and Resource Economics Department, Florida Cooperative Extension Service, Institute of Food and Agricultural Sciences, University of Florida, Gainesville, FL; Director, Agricultural Law Center, University of Florida, Gainesville, FL; and Chair, Agricultural Law Committee of The Florida Bar. Luke D'Isernia, former student (graduated cum laude in 2005), Levin College of Law, University of Florida, Gainesville, FL. Laura Minton, Attorney, Dean, Mead, Egerton, Bloodworth, Capouano, and Bozarth, Orlando, FL. Dulcy Miller, attorney, Foley and Lardner, LLP, Orlando, FL. Sarah Corbett, Attorney, Florida Second District Court of Appeal, Lakeland, FL.

The Institute of Food and Agricultural Sciences (IFAS) is an Equal Opportunity Institution authorized to provide research, educational information and other services only to individuals and institutions that function with non-discrimination with respect to race, creed, color, religion, age, disability, sex, sexual orientation, marital status, national origin, political opinions or affiliations. U.S. Department of Agriculture, Cooperative Extension Service, University of Florida, IFAS, Florida A. \& M. University Cooperative Extension Program, and Boards of County Commissioners Cooperating. Larry Arrington, Dean 
reclaiming solid wastes to the greatest extent practicable. Because improperly handled solid waste represents such a grave threat to water quality, it also falls within the scope of other federal regulations, most notably the National Pollutant Discharge Elimination System (NPDES) of the Federal Clean Water Act. NPDES is an EPA, and state, enforced system requiring permits for all point source pollution discharges into navigable waters (see FE602, Groundwater Discharge Regulation at the Federal Level).

Under the Federal Clean Water Act, Confined Animal Feeding Operations (CAFO) are considered a point source and are required to obtain an NPDES permit before they are allowed to operate.

Aside from the areas of special state and federal interest, local authorities are basically free to set their own rules, within broad state guidelines, for the collection and disposal of solid wastes. Cities, counties, or municipalities should be consulted regarding problems involving the locations of disposal facilities, frequency of waste pickup, and other day-to-day waste disposal questions.

\section{What Is Solid Waste?}

Solid waste has been defined as any garbage, refuse, sludge, or other discarded materials, and liquid, semi-solid, or contained gaseous materials. Furthermore, waste from agricultural activities is expressly included.

The only relevant materials that are expressly listed as not within the RCRA definition of solid waste are as follows:

- Solid or dissolved materials in domestic sewage.

- Solid or dissolved waste from irrigation return flows.

- Industrial discharges from point sources which are permitted for release under NPDES of the Clean Water Act.

- Source, special nuclear, or byproduct material as defined by the Atomic Energy Act of 1954.
If none of these exceptions apply, and if the material involved may be said to be discarded or to have served its useful purpose, it is a solid waste. Solid waste may be recycled, reused, discarded, reclaimed, or stored, depending upon its nature. Many solid wastes may also be hazardous wastes and subject to other, more restrictive regulations. Therefore the section on hazardous waste (FE612) must also be consulted when considering solid wastes.

NPDES coverage extends only to discharges into navigable waters and sets different standards for the amount of waste that may be discharged based upon:

- The type of industry involved.

- The toxicity of the waste.

- The acceptable maximum amounts of harmful elements which can be released into the body of water that is being polluted.

The broad definition of "navigable waters" is covered in FE582, Clean Water Act.

Facilities which are disposing of wastes in any way not in accordance with the federal RCRA guidelines or NPDES requirements for discharging water are deemed to be violators of the law.

\section{What Are Residuals?}

The DEP has established detailed regulations controlling the application of residuals (sludge) to land. Residuals are solid, liquid, or semisolid residues generated during the treatment of domestic wastewater in a domestic wastewater treatment facility. Residuals can be applied to land only if the facility generating or treating the residuals has a valid permit which includes an approved Agricultural Use Plan for the application site. Residuals are classified as either Class A or Class B with respect to the pathogen reduction requirements set forth by the Environmental Protection Agency as follows:

- Class A residuals are allowed on unrestricted public areas such as playgrounds, parks, golf courses, lawns, and hospital grounds. 
- Class B residuals are not allowed on unrestricted public access areas. Class B residual use is restricted to public access areas (e.g., agricultural sites, forests, and roadway shoulders and medians) and the public shall be restricted from the application zone for twelve months after the last application of the residuals. Additional restrictions apply when residuals are applied to soil in which food crops are grown and harvested and where animals graze on the application site.

Cautions that apply to the use or disposal of residuals include the following:

- Residuals may never be dumped into oceans, or surface or ground waters.

- Residuals must not be discharged into a collection or transmission system without prior consent of the owner of that system.

- Residuals containing hazardous wastes may never be applied to agricultural lands, and may require disposal under more restrictive, hazardous waste regulations.

\section{How Is Used Oil Regulated?}

Both state and federal laws are consistent in their prohibitions against the haphazard disposal of used oil. It is clearly a violation to:

- Discharge oil into soils, sewers, drainage systems, septic tanks, surface or ground waters, watercourses, or marine waters.

- Dispose of oil in a landfill, or commingle (mix) oil with other wastes for the purpose of disposing of it in a landfill.

- Commingle (mix) used oil with hazardous substances that make the used oil unsuitable for recycling or beneficial use.

- Release used oil into the environment through any process, including weed control, dust control, road oiling, or other similar uses.

Furthermore, all processors and transporters of used oil must register with the DEP annually, and all facilities for handling used oil must obtain DEP permits.

\section{What Can Be Composted from Waste?}

The DEP has established detailed regulations for the production and use of compost created from waste. The scope of these regulations does not encompass the use of compost obtained from normal farming operations on the land where it was generated.

You May Compost:

- Wastes produced in "normal farming operations" such as activities used in the production of poultry, livestock, or agricultural crops. Normal waste from these operations includes organic waste, manure, and wastes derived solely from agricultural crops.

- Any facilities producing compost for sale must obtain permits from the DEP and comply with detailed DEP regulations.

You May Not Compost:

- Compost from solid waste may never be used as fill material in any body of surface water.

- DEP regulations prohibit any application of compost that would endanger public health or the environment.

\section{What Sould Not Go into Landfills?}

Florida has taken an interest in limiting the types of solid waste to be disposed of through landfills, and has specifically prohibited the use of landfills to dump:

- Used oil.

- Lead-acid batteries.

- Yard trash.

- White goods (meaning discarded appliances like refrigerators or water heaters). 
The burning of solid waste is also prohibited except under the conditions expressly approved by the rules for disposal facilities.

\section{Source}

42 United States Code, Sections 6901 to 6987; 40

Code of Federal Regulations, Section 240 et seq; 33

United States Code, Sections 1251 to 1387; Chapter

403, Florida Statutes, Sections 403.702 to 403.7893;

Title 17, Florida Administrative Code

\section{Contact Information}

Solid Waste Management (FE616, Contact Agencies)

- S-2, Florida Department of Environmental Protection

- L-4, Emergency Superfund Branch

- L-5, Clean Water Act Facilities and Performance

- F-3, Emergency Planning and Community Right-to-Know Act

- F-5, National Pesticide Institution Network

\section{Acknowledgments}

The authors are indebted to the personnel of both state and federal agencies who provided their time and advice in the preparation of this handbook. The authors are especially indebted to Richard Budell of the Office of Agricultural Water Policy of the Florida Department of Agriculture and Consumer Services for providing funds for the development of this publication. 